\title{
Interpretation of the full blood count in systemic disease - a guide for the physician
}

\author{
M Leach \\ Consultant Haematologist and Honorary Senior Lecturer, Gartnavel Hospital, Glasgow, UK
}

\begin{abstract}
The full blood count (FBC) is perhaps the single most common investigation performed in medical patients. It has the potential, when interpreted carefully and in relation to the clinical history, to provide very useful information to assist in diagnosis and management. Clinicians are often alerted to the presence of a primary haematological disorder by abnormalities in the FBC. For the purpose of this review these diseases will not be discussed in detail but the reader will be alerted to pointers which might indicate primary blood disorders throughout the text. The haematology laboratory in large teaching hospitals will often provide up to I,500 automated FBC analyses each day. These are individually checked for 'flags' provided by the analyser which indicate values outside the normal range. It is clearly essential that clinical information is provided with the request as this will influence how the result is handled by scientific and medical staff. Furthermore, significant abnormalities will generate a blood film request and the report will be most useful when interpreted in light of the patient's working diagnosis. In cases where a diagnosis is not yet known, even brief information on presentation, for example 'collapse with hypotension', 'fever on return to UK', 'weight loss and anorexia', can all be important and help the lab provide clinicians with guidance.
\end{abstract}

This short review aims to provide physicians with a workable guide to the interpretation of some of the commoner findings in the full blood count. Some of these will be very familiar to you but some will not. This review is not meant to be exhaustive as the rare minutiae will obscure the essential core material. Your haematology colleagues are always happy to help and available for assistance in difficult or problematic cases. I have not specified normal ranges in relation to each entity as these will be defined by your local laboratory.

KEYWORDS Full blood count, infection, inflammation, neoplasia, anaemia, systemic disease

DECLARATIONS OF INTERESTS No conflicts of interest declared.

\author{
Correspondence to $M$ Leach \\ Department of Haematology \\ Leukaemia Research Lab \\ Shelley Road \\ Gartnavel Hospital site \\ Glasgow GI2 OYN, UK \\ e-mail \\ mike.leach@ggc.scot.nhs.uk
}

\section{OVERVIEW}

\section{Haemoglobin}

Anaemia is a common finding in medical patients. It is best characterised in relation to the mean cell volume (MCV). The important causes of microcytic anaemia $(\mathrm{MCV}<80 \mathrm{fl})$ are outlined below in order of frequency. In the presence of microcytosis with hypochromia (low mean cell haemoglobin $[\mathrm{MCH}]$ ) it is essential to check a serum ferritin assay. A low serum ferritin is diagnostic of iron deficiency. Ferritin levels, however, can be elevated in the acute phase response often in parallel to the erythrocyte sedimentation rate (ESR) so a normal ferritin does not exclude iron deficiency. A ferritin level over $100 \mathrm{ng} / \mathrm{ml}$ virtually excludes iron deficiency regardless of circumstances. A mild microcytosis may be seen in anaemia of chronic disease (discussed below) but the MCV is rarely less than $70 \mathrm{fl}$ and the serum ferritin is normal. The thalassaemias and thalassaemia traits frequently cause microcytosis and hypochromia but the serum ferritin is normal. If thalassaemia trait is suspected in the presence of a low ferritin it is important to correct the iron deficiency before requesting a haemoglobinopathy screen.

The finding of a macrocytic anaemia/macrocytosis is also of diagnostic importance. The differential diagnosis is summarised in Table 2.

A normochromic normocytic anaemia (MCV 80-100 fl) is frequently present in hospitalised patients. It can result from blood loss or may be a reflection of the effects of ongoing systemic infective, inflammatory, and neoplastic disorders and chronic organ failure, when it is known as anaemia of chronic disease (ACD) or anaemia of 
TABLE I Causes of microcytic anaemia

\begin{tabular}{|l|l|l|l|l|l|l|}
\hline & $\begin{array}{l}\text { Mean cell } \\
\text { volume (f) }\end{array}$ & $\begin{array}{l}\text { Mean cell } \\
\text { haemoglobin } \\
\text { (pg/ml) }\end{array}$ & $\begin{array}{l}\text { Ferritin (ng/ } \\
\mathbf{m l})\end{array}$ & $\begin{array}{l}\text { Red blood } \\
\text { cell count } \\
\left(\mathbf{x} / \mathbf{0}^{12} / \mathbf{L}\right)\end{array}$ & Blood film & History \\
\hline Iron deficiency & $\begin{array}{l}<80, \\
\text { occasionally } \\
\text { normal }\end{array}$ & Low & $\begin{array}{l}\text { Low (normal } \\
\text { if acute phase } \\
\text { response) }\end{array}$ & Low & $\begin{array}{l}\text { Target cells } \\
\text { Pencil cells }\end{array}$ & Bleeding \\
\hline $\begin{array}{l}\text { Anaemia } \\
\text { chronic disease }\end{array}$ & $\begin{array}{l}70-80, \text { often } \\
\text { normal }\end{array}$ & Normal & Normal or high & Low & $\begin{array}{l}\text { No specific } \\
\text { features }\end{array}$ & Medical disease \\
\hline $\begin{array}{l}\text { Thalassaemia/ } \\
\text { trait }\end{array}$ & $\begin{array}{l}\text { Low, often } \\
50-60\end{array}$ & Low & Normal & High & $\begin{array}{l}\text { Target cells } \\
\text { Poikilocytes } \\
\text { Tear drop cells } \\
\text { Nucleated red } \\
\text { blood cells }\end{array}$ & Ethnic origin \\
\hline $\begin{array}{l}\text { Lead poisoning } \\
\text { Row or normal }\end{array}$ & Normal & Normal & Normal & $\begin{array}{l}\text { Basophilic } \\
\text { stippling }\end{array}$ & $\begin{array}{l}\text { History of } \\
\text { exposure }\end{array}$ \\
\hline $\begin{array}{l}\text { Risorders, e.g. } \\
\text { sideroblastic } \\
\text { anaemia, } \\
\text { pyro- } \\
\text { poikilocytosis }\end{array}$ & Low & Normal & Normal & Low/Normal & $\begin{array}{l}\text { According to } \\
\text { condition }\end{array}$ & Congenital \\
\hline
\end{tabular}

TABLE 2 Causes of macrocytic anaemia

\begin{tabular}{|c|c|c|c|c|}
\hline & Full blood count & Blood film & History & Investigation \\
\hline $\begin{array}{l}\text { Vitamin B I } 2 \\
\text { deficiency }\end{array}$ & $\begin{array}{l}\text { May cause } \\
\text { pancytopenia }\end{array}$ & Oval macrocytes & $\begin{array}{l}\text { Pernicious anaemia } \\
\text { Ileal surgery }\end{array}$ & $\begin{array}{l}\mathrm{BI} 2 \text { assay } \\
\text { Intrinsic factor } \mathrm{Ab}\end{array}$ \\
\hline Folate deficiency & $\begin{array}{l}\text { May cause } \\
\text { pancytopenia }\end{array}$ & Oval macrocytes & $\begin{array}{l}\text { Diet } \\
\text { Coeliac disease }\end{array}$ & $\begin{array}{l}\text { Serum folate } \\
\text { TTG Ab } \\
\text { Duodenal Bx }\end{array}$ \\
\hline Liver disease & Thrombocytopenia & $\begin{array}{l}\text { Regular macrocytes } \\
\text { Target cells }\end{array}$ & $\begin{array}{l}\text { Alcohol } \\
\text { Hep B, C, } \\
\text { etc. }\end{array}$ & According to history \\
\hline Hypothyroidism & $\begin{array}{l}\text { Normal WBC and } \\
\text { platelets }\end{array}$ & Unhelpful & $\begin{array}{l}\text { Thyroiditis } \\
\text { Radiotherapy }\end{array}$ & According to history \\
\hline $\begin{array}{l}\text { Hereditary } \\
\text { haemochromatosis }\end{array}$ & Normal Hb & $\begin{array}{l}\text { Unhelpful } \\
\text { Mild macrocytosis }\end{array}$ & Family history & $\begin{array}{l}\text { HFE gene studies } \\
\text { Ferritin } \\
\text { Transferrin saturation }\end{array}$ \\
\hline Drug therapy & Variable & Unhelpful & $\begin{array}{l}\text { Azathioprine } \\
\text { Mercaptopurine } \\
\text { Folate antagonists } \\
\text { Hydroxycarbamide }\end{array}$ & According to history \\
\hline $\begin{array}{l}\text { Haemolysis with } \\
\text { reticulocytosis }\end{array}$ & Anaemia & $\begin{array}{l}\text { Spherocytes } \\
\text { Bite cells } \\
\text { polychromasia }\end{array}$ & $\begin{array}{l}\text { Drugs } \\
\text { Systemic lupus } \\
\text { erythematosus (SLE) } \\
\text { Lymphoma }\end{array}$ & $\begin{array}{l}\text { Retic count } \\
\text { Direct Coombs test } \\
\text { Bilirubin } \\
\text { Haptoglobin }\end{array}$ \\
\hline $\begin{array}{l}\text { Myelodysplastic } \\
\text { syndrome }\end{array}$ & $\begin{array}{l}\text { May cause } \\
\text { pancytopenia }\end{array}$ & Dysplastic neutrophils & Exclude other causes & $\begin{array}{l}\text { Bone marrow (BM) } \\
\text { biopsy } \\
\text { Marrow cytogenetics }\end{array}$ \\
\hline $\begin{array}{l}\text { Plasma cell } \\
\text { dyscrasias }\end{array}$ & Anaemia & Rouleaux & $\begin{array}{l}\text { Bone pain } \\
\text { Fractures } \\
\text { Renal failure }\end{array}$ & $\begin{array}{l}\text { Immunoglobulins } \\
\text { Serum electrophoresis } \\
\text { Serum free light chains } \\
\text { BM biopsy }\end{array}$ \\
\hline
\end{tabular}


TABLE 3 Causes of polycythaemia

\begin{tabular}{|l|l|l|l|l|}
\hline Type & Red cell mass & Plasma volume & Erythropoietin level" & Causes \\
\hline $\begin{array}{l}\text { Myeloproliferative } \\
\text { disease (MPD) } \\
\text { (primary } \\
\text { polycythaemia) }\end{array}$ & Raised & Normal & Low & $\begin{array}{l}\text { Janus kinase 2 gene } \\
\text { JAK2) mutation }\end{array}$ \\
\hline $\begin{array}{l}\text { Secondary } \\
\text { polycythaemia } \\
\text { with hypoxia }\end{array}$ & Raised & Normal & Normal & $\begin{array}{l}\text { Chronic hypoxia due } \\
\text { to cardiopulmonary } \\
\text { diseases, smoking, high } \\
\text { altitude }\end{array}$ \\
\hline $\begin{array}{l}\text { Secondary } \\
\text { polycythaemia } \\
\text { without hypoxia }\end{array}$ & Raised & Normal & High & $\begin{array}{l}\text { Ectopic erythropoietin } \\
\text { (Renal tumours/cysts, } \\
\text { hepatic tumours, } \\
\text { fibroids, cerebellar } \\
\text { tumours) }\end{array}$ \\
\hline $\begin{array}{l}\text { Spurious or } \\
\text { apparent } \\
\text { polycythaemia }\end{array}$ & Normal & Reduced & $\begin{array}{l}\text { Dehydration } \\
\text { Diuretics } \\
\text { Alcohol } \\
\text { Stress }\end{array}$ \\
\hline
\end{tabular}

"Erythropoietin levels are mainly of use in secondary polycythaemia due to ectopic production. In routine practice, levels in the other groups are often normal.

inflammation (Al). These patients have a normal or raised serum ferritin and normal reticulocyte count and do not respond to iron replacement therapy. In parallel, it is common to find elevated polyclonal gammaglobulins and raised ESR or C-reactive protein (CRP) in inflammatory and infective disorders, respectively. In any patient with such an anaemia and raised ESR it is clearly important to perform serum electrophoresis to exclude a paraprotein and possible plasma cell dyscrasia. The anaemia in ACD will only respond to effective management of the underlying disorder though in renal anaemia with erythropoietin deficiency it will often respond to erythropoietin replacement. Anaemia of chronic disease is a secondary anaemia that results from cytokine-mediated suppression of bone marrow erythroid activity and shortened red cell lifespan. When present, it should always lead the physician to consider its cause. It is an important anaemia to recognise as in some patients it can be the first manifestation of an occult tumour. The anaemia resolves when the tumour is excised.

Polycythaemia (abnormal high haemoglobin and haematocrit) may be the result of a primary myeloproliferative disorder (MPD), particularly if associated with neutrophilia, thrombocytosis, and splenomegaly. Over $90 \%$ of patients with primary polycythaemia and approximately $50 \%$ of those with myelofibrosis and essential thrombocythaemia harbour a mutation (V6I7F) in the Janus kinase 2 gene (JAK2) which renders haemopoietic cells more sensitive to growth factors. This mutation can be detected by polymerase chain reaction (PCR) studies on peripheral blood and shows high specificity for myeloproliferative diseases so is very helpful in diagnosis. The presence of this mutation will often mean that investigations such as blood volume studies and erythropoietin levels are not necessary. Polycythaemia is relatively frequently seen as a sole abnormality of the full blood count in medical patients in the circumstances outlined in Table 3 (compared with primary polycythaemia). In many patients the cause will be obvious but in others the finding may be unexpected.

\section{Leucocytes}

Changes in peripheral leucocyte count can be highly informative in medical practice and the cell line involved can be specific to certain scenarios.

Neutrophilia is commonly seen in patients with bacterial infection. The most severe infections are associated with more marked neutrophilia and often a degree of myeloid left shift (the presence of immature myeloid cells in peripheral blood) with 'toxic' neutrophil granulation. Neutrophilia may also be seen in non-infective disorders. It is a common response to steroid therapy, severe exercise, and following surgery or splenectomy, but can also occur in systemic vasculitis, in the presence of tissue necrosis/burns, and as a response to certain tumours (summarised below).

\section{- Bacterial infection}

- Steroid therapy

- Post-surgery

- Extreme exercise

- Tissue necrosis

- Burns

- Systemic vasculitis

- Carcinoma 
Isolated neutropenia can be seen in connective tissue disorders, particularly rheumatoid arthritis and Sjogren's disease. It can be a result of drug therapy, e.g. clozapine, azathioprine, carbimazole, such that patients need careful regular monitoring when treated with these agents. It is of course seen following cytotoxic chemotherapy. It is commonly seen following viral infection e.g. Epstein-Barr virus infection, when it tends to be mild and self-limiting. A sudden onset neutropenia can be seen in patients with overwhelming bacterial infection and appears to be a poor prognostic sign. A significant persisting neutropenia requires the opinion of a haematologist particularly in patients with cytopenias in other lineages. Mild chronic neutropenias not associated with infection are reasonably common and are sometimes referred to as benign idiopathic neutropenia. Finally, Afro-Caribbean patients commonly show mild neutropenia below the normal range seen in Caucasians: this racial neutropenia should be recognised as such and not generate unnecessary investigations.

Eosinophilia is a much less common finding in clinical practice but the search for a likely cause is often rewarding. Mild eosinophilia is common in patients with asthma, hayfever, and eczema but rarely exceeds $1.0 \times$ $10^{\circ} / \mathrm{L}$. Some of the more common causes are listed in Table 4.

\section{TABLE 4 Causes of eosinophilia}

\begin{tabular}{|l|l|}
\hline Cause & Condition \\
\hline $\begin{array}{l}\text { Connective tissue } \\
\text { diseases }\end{array}$ & $\begin{array}{l}\text { Churg-Strauss syndrome } \\
\text { Idiopathic eosinophilic } \\
\text { pneumonia }\end{array}$ \\
\hline Parasitic infections & $\begin{array}{l}\text { Carcinoma } \\
\text { T cell lymphoma } \\
\text { Hodgkin lymphoma } \\
\text { Myeloproliferative disorders } \\
\text { Myeloid and eosinophilic } \\
\text { leukaemias }\end{array}$ \\
\hline Allergy & $\begin{array}{l}\text { Asthma, hayfever, eczema } \\
\text { Drug hypersensitivity } \\
\text { Food allergy }\end{array}$ \\
\hline
\end{tabular}

A few cases remain unexplained and were previously known as hypereosinophilic syndrome but these patients are increasingly rare now that molecular diagnostics are able to characterise many of these as clonal eosinophilic leukaemias.

Lymphocytosis is commonly seen as a result of viral infection often with a mild self-limiting neutropenia as noted above. Stress lymphocytosis is a relatively common phenomenon in hospital patients and is precipitated by acute onset illnesses such as myocardial infarction, major trauma, and status epilepticus.The lymphocytosis appears abruptly and resolves within a few days of the insult. Mild lymphocytosis is also seen post-splenectomy and can also be a result of smoking. A persistent significant lymphocytosis (lymphocyte count $>6 \times 10^{\circ} / \mathrm{L}$ ) requires a haematology opinion and exclusion of a chronic lymphoproliferative disorder.

Lymphopenia is a common result of therapy with steroids and other immunosuppressive agents, e.g. azathioprine. It is seen in advanced HIV infection, can be a presenting feature in patients with Hodgkin lymphoma, and is associated with rheumatoid arthritis, systemic lupus, and sarcoidosis. Mild lymphopenia is a relatively common finding in a routine FBC and in the absence of any other specific symptoms should not trigger extensive investigations. In my experience, the investigation of mild isolated lymphopenia is rarely rewarding.

Monocytosis can be a feature in chronic infection with tuberculosis and syphilis, as part of the inflammatory reaction in Crohn's disease and ulcerative colitis and as a response to certain carcinomas. A persistent monocytosis that is unexplained, particularly if associated with anaemia or thrombocytopenia, may be a feature of myelodysplastic and myeloproliferative disorders, so a haematology assessment is advised in these cases.

\section{Platelets}

Thrombocytosis is commonly seen as a reactive phenomenon in patients with active chronic infection, inflammation, and malignancy. The longer the duration of these disease processes, the more likely is thrombocytosis to become evident. These patients will often show an elevation in other inflammatory markers in parallel and the blood film tends to show small relatively uniform platelets with little variation in size. Chronic bleeding and iron deficiency anaemia is frequently associated with thrombocytosis and it will resolve when the bleeding source and iron deficiency is corrected. Reactive thrombocytosis, and the thrombocytosis seen after splenectomy, accounts for the majority of cases seen in general medical practice. Thrombocytosis is also a feature of a number of myeloproliferative disorders, often in association with abnormalities in the haemoglobin or platelet count. These cases will not show elevation of inflammatory markers and the blood film typically shows large platelets with wide variation in individual size. As noted above, testing for the JAK2 mutation can be very helpful in diagnosis. These patients are at increased risk of vascular occlusive events so it is important they are identified.

Thrombocytopenia is seen in a myriad of medical scenarios but it is important to establish that the thrombocytopenia is real and confirmed on a blood film. Spurious thrombocytopenia can result from in vitro platelet clumping in ethylenediaminetetraacetic acid 
(EDTA)-anticoagulated specimens. This is an idiosyncratic phenomenon seen in some patients and is not associated with disease. The two main groups of conditions causing true thrombocytopenia are firstly those associated with increased platelet consumption and secondly those causing bone marrow failure, as a result of primary haematological diseases, bone marrow infiltration, or fibrosis. The causes of consumptive thrombocytopenia are summarised in Table 5 and more than one mechanism can be active in any individual patient so careful sequential investigation, in light of the clinical history, is essential.

\section{TABLE 5 Causes of consumptive thrombocytopenia}

\begin{tabular}{|c|c|}
\hline Immune & $\begin{array}{l}\text { Idiopathic } \\
\text { Connective tissue disorders } \\
\text { Drugs } \\
\text { HIV infection }\end{array}$ \\
\hline \multicolumn{2}{|l|}{ Systemic sepsis } \\
\hline \multicolumn{2}{|l|}{ Viral infection } \\
\hline \multicolumn{2}{|l|}{ Heparin } \\
\hline Alcohol & Acute intoxication \\
\hline Hypersplenism & $\begin{array}{l}\text { Portal hypertension } \\
\text { Splenomegaly }\end{array}$ \\
\hline \multicolumn{2}{|l|}{ Massive transfusion } \\
\hline \multicolumn{2}{|l|}{ Cardiac bypass procedures } \\
\hline \multicolumn{2}{|l|}{ Post transfusion purpura } \\
\hline \multicolumn{2}{|l|}{ Multiorgan failure } \\
\hline Microangiopathy & $\begin{array}{l}\text { Haemolytic uraemic } \\
\text { syndrome } \\
\text { Thrombotic } \\
\text { thrombocytopenic purpura } \\
\text { Haemolysis, elevated liver } \\
\text { enzymes and low platelet } \\
\text { (HELLP) syndrome } \\
\text { Disseminated intravascular } \\
\text { coagulation }\end{array}$ \\
\hline
\end{tabular}

\section{SUMMARY}

The FBC can provide a wealth of important information which can assist the physician in patient diagnosis and management. It is essential to assess not only the current lab values but also to establish potential trends over time and in relation to known diagnoses, surgical interventions and drug treatment. The cause of many abnormalities will be obvious but any unexpected findings need explanation. Not only will this assist in achieving a prompt diagnosis in many patients but awareness of the common causes for each abnormality might prevent unnecessary investigations in others.

\section{Highlights}

- Abnormalities in the full blood count may be informative in all fields of medicine.

- Anaemia is a common finding in medical patients: assessment of the cause of anaemia is essential in patient management.

- It is important to recognise common reactive full blood count changes in patients presenting with active systemic disease.

- Certain reactive phenomena, e.g. eosinophilia may help direct investigations to achieve a specific diagnosis

- Persisting abnormalities in the full blood count that remain unexplained should prompt an opinion from a haematologist.

\section{Further reading}

I Hoffbrand AV, Pettit J, Moss P. Essential haematology. London: John Wiley and sons; $20 \mathrm{II}$.

2 Hoffbrand AV, Tuddenham EGD, Catovsky D et al. editors. Postgraduate haematology. London: John Wiley and Sons; 201 I. 


\section{SELF-ASSESSMENT QUESTIONS}

I. Which ONE of the following is not associated with thrombocytopenia?
A. Massive transfusion.
B. Haemolytic uraemic syndrome.
C. Secondary antiphospholipid syndrome.
D. Essential thrombocythaemia.
E. Portal hypertension.

2. Which ONE of the following is not characteristic in a patient presenting with a collapse due to an overwhelming bacterial infection?
A. Lymphocytosis.
B. Neutrophilia.
C. Neutropenia.
D. Thrombocytopenia.
E. Eosinophilia.

3. A 65-year-old male patient presents with a sixweek history of anorexia, weight loss, and lethargy. He is noted to have a low grade fever. The physical examination showed no specific findings. The full blood count showed $\mathrm{Hb} 90 \mathrm{~g} / \mathrm{L}$, MCV $72 \mathrm{fl}$,WBC $9 \times 10^{\circ} / \mathrm{L}$, platelets $600 \times 10^{\circ} / \mathrm{L}$. Serum ferritin was $120 \mathrm{ng} / \mathrm{ml}$, ESR was $50 \mathrm{~mm} / \mathrm{hr}$. Gammaglobulins were diffusely increased. The chest X-ray was normal.

Which ONE of the following would be an appropriate management plan?

A. Perform endoscopy and colonoscopy then give iron replacement.

B. Request a myeloma screen and skeletal survey.

C. Obtain urine, blood, and sputum for culture then commence empirical antibiotic therapy.

D. Request a bone marrow biopsy for morphology and culture.

E. Consider investigations for a systemic inflammatory/ connective tissue disorder or occult neoplasm.
4. A 45-year-old fireman presents with progressive numbness in his feet and some unsteadiness of gait. He was noted to be mildly icteric. The full blood count showed Hb IIO g/L, MCV I3 I fl, WBC $4 \times 10^{\%} / L$, platelets $120 \times 10^{\circ} / L$. Serum LDH was $800 \mathrm{U} / \mathrm{ml}$.

Which ONE of the following would be an appropriate first line of management?

A. Arrange imaging of the liver and biliary tree.

B. Arrange outpatient EMG studies and a neurology opinion.

C. Check a serum BI2 assay and commence intramuscular BI2 therapy.

D. Request an outpatient haematology opinion.

E. Arrange MRI imaging of the brain and spinal cord.

5. A 25-year-old man with a history of childhood asthma presented with a six-week history of fever and night sweats. Physical examination was unremarkable. The full blood count showed $\mathbf{H b}$ $120 \mathrm{~g} / \mathrm{L}, \mathrm{MCV} 9 \mathrm{I} \mathrm{fl}, \mathrm{WBC}$ I $\times 10^{\circ} / \mathrm{L}$, neutrophils 5 x $10^{9} / \mathrm{L}$, lymphocytes $0.6 \times 10^{9} / \mathrm{L}$, eosinophils $4 \times$ $10^{\circ} / \mathrm{L}$, platelets $450 \times 10^{\circ} / \mathrm{L}$.

Which ONE of the following is a priority investigation?
A. Chest X-ray.
B. Blood, urine and sputum cultures including investigations for TB.
C. Serology and blood films for helminths.
D. HIV serology.
E. Spirometry with reversibility.

This paper was originally published as part of the Haematology module on the RCPE Online Education Portal. Specialty Modules for continuing medical education, including the answers to these questions, are available to Fellows and Members at http:llearning. rcpe.ac.uk 